\title{
Physician preferences for working in deprived areas: a systematic review of discrete choice experiment
}

\author{
Pejman Hamouzadeh ${ }^{1}$, Ali Akbarisari*1, Alireza Olyaeemanesh ${ }^{2,3}$, Mir-Saeed Yekaninejad ${ }^{4}$ \\ Received: 19 Jul 2018 \\ Published: 14 Aug 2019
}

\begin{abstract}
Background: Physician shortages in rural areas is a universal concern, and most countries face this challenge. Many attributes influence the physician preferences about the choice of working location. The aim of this systematic review was to investigate which attributes were included in discrete choice experiment studies and which of them valued the most by physicians.

Methods: The following databases were searched: PubMed, Embase, and Web of Science Core Collection. Further studies were retrieved from reference lists of included studies, and grey literature. Studies used discrete choice experiments methods to elicit preferences for working in the deprived area, focus on physicians or medical students, and published between 2000 and 2017 in the English language were included.

Results: The literature search yielded 192 studies, of which 14 studies met inclusion criteria. The attributes and attribute levels were identified by literature review and qualitative research. The number of attributes varied from five to ten, and the most frequent number was six attributes. In most studies, maximum of sixteen different scenarios were given to the study samples. The "salary or income" attribute was the most important in fifty percent of the studies and the attributes related to "study and education" was at the next level.

Conclusion: Financial attributes are not the only significant attributes considered by the physicians for deciding where to practice, but also the other non-financial attributes are important. It is suggested that based on the economic, social and cultural conditions of each country, a specific incentive package, including a set of financial and non-financial incentives, is developed to attract physicians to the deprived areas.
\end{abstract}

Keywords: Physician, Discrete choice experiment, Preference, Deprived area, Systematic review

Conflicts of Interest: None declared

Funding: Tehran University of Medical Sciences

*This work has been published under CC BY-NC-SA 1.0 license.

Copyright $\odot$ Iran University of Medical Sciences

Cite this article as: Hamouzadeh P, Akbarisari A, Olyaeemanesh A, Yekaninejad MS. Physician preferences for working in deprived areas: a systematic review of discrete choice experiment. Med J Islam Repub Iran. 2019 (14 Aug);33:83. https://doi.org/10.47176/mjiri.33.83

\section{Introduction}

Inadequate number of qualified health personnel in deprived areas impedes equity access to healthcare and the health demands of the population. Therefore, encouraging physicians to work in deprived areas is the biggest challenge facing health system policymakers $(1,2)$. There is an alarming shortage of health personnel such as physicians in deprived areas in both developing and developed countries. In Canada (3) and the United States (4), about $9 \%$ of physicians live in remote areas, while less than a

\footnotetext{
Corresponding author: Dr Ali Akbarisari, akbarisari@tums.ac.ir

1. Department of Health Management and Economics, School of Public Health, Tehran University of Medical Sciences, Tehran, Iran

2. National Institute for Health Research, Tehran University of Medical Sciences, Tehran, Iran

3. Health Equity Research Center, Tehran University of Medical Sciences, Tehran, Iran

4. Department of Epidemiology and Biostatistics, School of Public Health, Tehran University of Medical Sciences, Tehran, Iran
}

quarter of the population live in these areas. In Senegal, the Dakar region has more than $60 \%$ of the country's physicians, but have only $23 \%$ of the total population (5). In Sudan, the physician-to-population ratio in the urban area is 24 times higher than in rural area (6). In India, nearly three-fifths of health workers be in urban areas with almost one-quarter of the country's population (7).

Studying the job preferences of physicians toward working in deprived areas, plays an important role in iden-

$\uparrow$ What is "already known" in this topic:

Despite numerous attempts to encourage physicians to work in deprived areas, this issue continues to be a major challenge for the health system in most countries.

\section{$\rightarrow$ What this article adds:}

For persuading the physician for practice in the deprived areas, a specific incentive package including financial and nonfinancial incentives must be provided to them. 
tifying attraction or retention incentives for physicians in this area. A technique that has been widely used for this purpose is the discrete choice experiment (DCE). DCE is an appropriate technique to elicit the stated preferences (8). DCE systematically quantifies the job preferences of physicians, and measure the trade-offs physicians place on various attributes of a job (9). DCE has been used to elicit health personnel preferences about working in the deprived area in several studies (10-18).

The aim of this systematic review was to investigate which attributes were included in discrete choice experiments studies and which of them valued the most by physicians. The results of this review can offer useful information on where attributes policies should be focused to improve the attraction and retention of physicians in deprived areas.

\section{Methods}

\section{Sources}

The following databases were systematically searched: PubMed, Embase, and Web of Science Core Collection. Further relevant studies were retrieved from reference lists of included studies, and grey literature.

\section{Search study}

Medical Subject Headings (MeSH) or free-text were used in three concepts.

Physician: "physician", “doctor", "surgeon", "medical" or "practitioner".

Deprived area: "rural", "remote", "deprived area", "underdeveloped area", "underserved area" or "disadvantaged area".

Discrete choice experiment: "discrete choice", "choice method", "choice experiment", "choice analysis", "choice modelling", "stated preference", "job preference" or "job attribute" (Appendix 1).

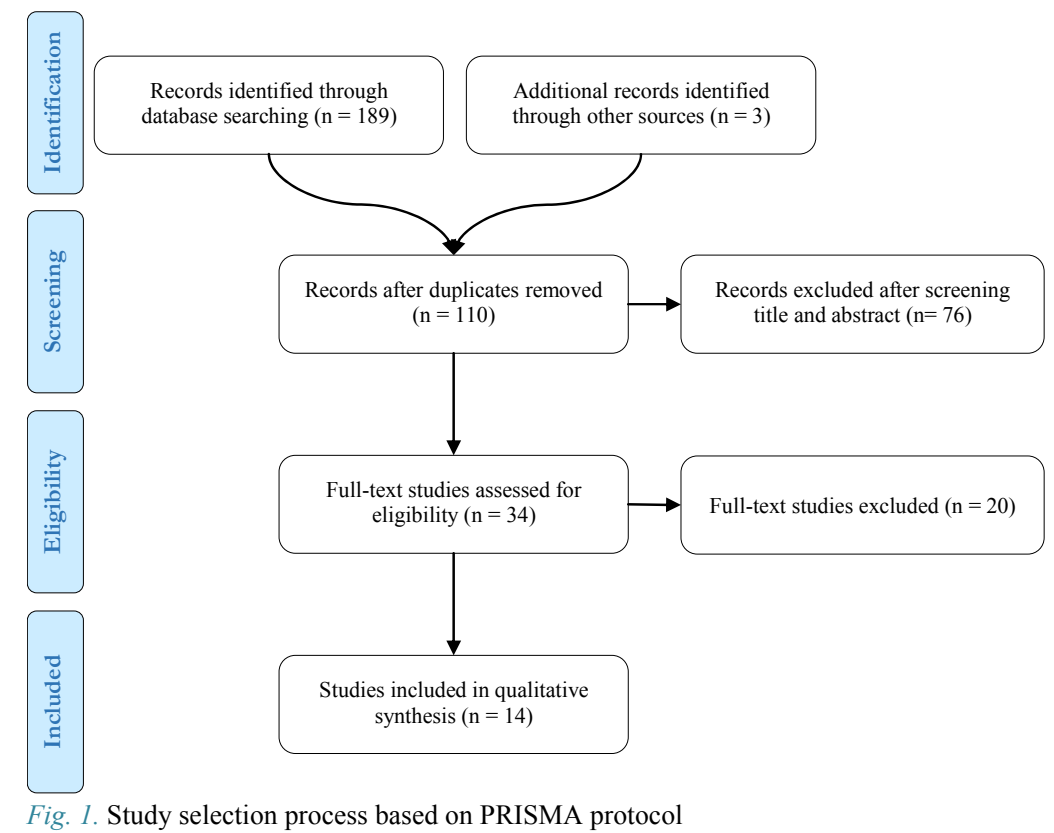

\section{Inclusion and exclusion criteria}

Studies were included in this review if they were: (a) an original study, (b) used discrete choice experiments methods to elicit preferences for working in the deprived area, (c) focus on physicians or medical students, and (d) published between 2000 and 2017 in the English language.

Studies were excluded if they were focused on nonphysician workforce, not written in the English language, and published before 2000 .

\section{Selection process}

For the selection of studies, two levels of screening were used. At first, titles and abstracts of studies screened by two reviewers independently to select potentially eligible studies. And then, the full-texts of potentially eligible studies, selected by at least one reviewer, were obtained and evaluated by two reviewers independently to see whether they met the inclusion criteria. Disagreements among the reviewers were resolved through consensus or by a third reviewer.

\section{Data extraction}

The data of included studies were extracted using a checklist designed by the researchers. The following data were extracted from the included studies: authors, country, year of study, sample size, response rate, attributes, levels, number of scenarios, and most important attribute.

\section{Results}

\section{Study selection}

The literature search yielded 192 studies: 57 from PubMed, 69 from Embase, 63 from Web of Science Core Collection, and three through the additional hand search. Eighty-two duplicates were removed, and after the exclusion by titles and abstracts, 34 studies were included in the full-text review. Of the 34 studies reviewed in detail, 20 were excluded [focus on non-physician workforce $(n=7)$, and not related to our aim $(n=13)]$. Finally, 14 DCE stud- 
ies $(15-28)$ were included in this systematic review (Fig. $1)$.

\section{Study characteristics}

The main characteristics of the included studies are shown in table 1 . Almost $70 \%$ of included studies have been published in the last 5 years. The number of attributes varied from five to ten, and the most frequent number was six attributes $(n=6)$. The number of scenarios varied from nine to twenty-four. In most studies, maximum of sixteen different scenarios were given to the study samples $(n=6)$. The sample of seven studies were in-service physicians, in five studies were medical students and in two studies were both in-service physicians and medical students. In all, 4004 in-service physician and 2594 medical students investigated in the included studies. The sample size was $<500$ in twelve and $>500$ in two of the studies. Most of the studies had a response rate of more than $80 \%$. Two studies reported a response rate of less than $60 \%$ and one study between $60 \%$ and $80 \%$. Most studies were conducted in Asia (16, 17, 19, 23-25, 28). Other studies were performed in Africa $(20,22,26,27)$, America $(15,18)$, and Europe (21) (Table 1).

\section{Attributes and attribute-levels}

Researchers used different methods to identify the attributes and levels. The most widely used methods in the included studies were qualitative research such as interviews and focus group discussions (FGD) $(n=13)$. Five studies used literature review methods to identify attributes and attribute-levels. Some studies used a combination of methods to identify attributes. For example, Rana and Sarfraz (16) performed a literature review with three indepth interviews and six FGD with senior health managers, medical officers, and medical students to identify attributes and attribute-levels. Overall, 4 studies (29\%) used two common methods (literature review and qualitative research) to identify attributes and attribute levels, and one study did not report the method of identifying the attributes (Table 2).

\section{Preferences for physicians to work in rural areas}

An overview of the attributes, levels and the most important attribute in each study are shown in table 3. Based on the results of the included DCE studies, the attribute
Table 1. Main characteristics of included studies

\begin{tabular}{lc}
\hline & Number of studies (\%) \\
\hline Sample & $7(50 \%)$ \\
In-service physicians & $5(36 \%)$ \\
Medical students & $2(14 \%)$ \\
Both & \\
Number of attributes & $1(7 \%)$ \\
5 attributes & $6(43 \%)$ \\
6 attributes & $4(29 \%)$ \\
7 attributes & $2(14 \%)$ \\
8 attributes & $1(7 \%)$ \\
10 attributes & \\
Number of Scenarios & $5(36 \%)$ \\
12 or less scenarios & $7(50 \%)$ \\
$13-16$ scenarios & $2(14 \%)$ \\
17 or more scenarios & \\
Sample size & $12(86 \%)$ \\
$<500$ & $2(14 \%)$ \\
$>500$ & \\
Response rate & $2(14 \%)$ \\
$<60 \%$ & $1(7 \%)$ \\
$60 \%-80 \%$ & $11(79 \%)$ \\
$>80 \%$ & \\
Continent & $4(29 \%)$ \\
Africa & $2(14 \%)$ \\
America & $7(50 \%)$ \\
Asia & $1(7 \%)$ \\
Europe &
\end{tabular}

Table 2. Methods to identify attributes and attribute-levels

Methods Number

Literature review 4

Qualitative research 13

Not-reported

The sum is greater than included studies and the percentage is more than $100 \%$, because some studies used more than one method

"salary or income" was the most important in fifty percent of the studies $(15,16,18,20,23,24,26)$. All the study concluded that higher salary or income had the biggest impact on the willingness of in-service physicians or medical students to work in deprived areas. Although the results of most studies $(50 \%)$ showed that increase income was the most important attributes from the viewpoint of respondents, Holte et al. (21) showed that increased income seem to have less impact as compared to improvements in the non-pecuniary attributes. Furthermore, four studies showed that attributes related to "study and education", such as "receiving study assistance" (19), "providing long-term education" (17), "tuition for future schooling" (27), and "training and education" (28) had the highest importance for the respondents. The results of other

Table 3. Overview of attributes, attribute levels, and main results

\begin{tabular}{|c|c|c|c|c|}
\hline No. & $\begin{array}{c}\text { Authors, } \\
\text { year }\end{array}$ & Country & Attributes (Levels) & Important attribute \\
\hline 1 & $\begin{array}{c}\text { Hanson, } \\
2010\end{array}$ & Ethiopia & $\begin{array}{l}\text { 1. Location (Addis Ababa vs. Zonal capital), 2. Monthly pay (Base/ Base }+50 \% / \text { Base }+100 \% \text { ), } 3 \text {. } \\
\text { Housing (None/ Basic/ Superior), } 4 \text {. Equipment and drugs at facility (Inadequate vs. Improved), } 5 \text {. } \\
\text { Time commitment per year of training (Two years vs. One year), 6. Private-sector work permitted } \\
\text { (Yes vs. No) }\end{array}$ & Higher wages \\
\hline 2 & $\begin{array}{l}\text { Kruk, } \\
2010\end{array}$ & Ghana & $\begin{array}{l}\text { 1. Salary (Base/ Base }+30 \% / \text { Base }+50 \% / \text { Base }+100 \%), 2 \text {. Children's education (No allowance vs. } \\
\text { Allowance), 3. Infrastructure (Basic vs. Advanced), } 4 \text {. Management style (Supportive vs. Unsup- } \\
\text { portive), } 5 \text {. Years of work before study leave ( } 5 \text { years vs. } 2 \text { years), } 6 \text {. Housing (Not provided/ Free } \\
\text { basic provided/ Free superior provided), } 7 \text {. Transportation (Utility car not provided vs. Utility car } \\
\text { provided) }\end{array}$ & Improved equipment \\
\hline 3 & $\begin{array}{c}\text { Vujicic, } \\
2011\end{array}$ & Vietnam & $\begin{array}{l}\text { 1. Location (Remote rural area vs. Urban center area), 2. Equipment (Inadequate vs. Adequate), } 3 . \\
\text { Official Income ( } 4 \text { million VND/ } 8 \text { million VND/ } 12 \text { million VND/ } 16 \text { million VND/ } 20 \text { million } \\
\text { VND), } 4 \text {. Skills Development (No program vs. Short-term courses), } 5 \text {. Long-term Education (None } \\
\text { vs. Possibility to enter advanced medical school after } 5 \text { years on the job); } 6 \text {. Housing (None vs. } \\
\text { Government-provided) }\end{array}$ & Long-term education \\
\hline
\end{tabular}




\begin{tabular}{|c|c|c|c|c|}
\hline No. & $\begin{array}{c}\text { Authors, } \\
\text { year }\end{array}$ & Country & Attributes (Levels) & $\begin{array}{l}\text { Important } \\
\text { attribute }\end{array}$ \\
\hline 4 & $\begin{array}{c}\text { Miranda, } \\
2012\end{array}$ & Peru & $\begin{array}{l}\text { 1. Type of health facility (Health center vs. Regional hospital), } 2 \text {. Monthly salary ( } 2,500 \text { PEN }^{*} / 3,125 \\
\text { PEN } \\
\text { Points when applying for a residency in Community and Family Medicine, after } 3 \text { years in post (10 } \\
\text { points vs. } 20 \text { points), } 5 \text {. Free housing provided (A shared room in a residence with shared facilities vs. A } \\
\text { two-bedroom independent house), } 6 \text {. Work schedule (You work } 22 \text { days and then have } 8 \text { days off vs. } \\
\text { You work } 18 \text { days and then have } 12 \text { days off), } 7 \text {. Free days for continuous medical education ( } 7 \text { free } \\
\text { days a year vs. } 14 \text { free days a year) }\end{array}$ & $\begin{array}{c}\text { Increased } \\
\text { salary }\end{array}$ \\
\hline 5 & $\begin{array}{c}\text { Rockers, } \\
2012\end{array}$ & Uganda & $\begin{array}{l}\text { 1. Salary per month ( } 700,000 \mathrm{USh} / 1,000,000 \mathrm{USh} / 1,500,000 \mathrm{USh} / 2,000,000 \mathrm{USh}), 2 \text {. Facility quality } \\
\text { (Basic vs. Advanced), 3. Housing (No housing or allowance provided/ Housing allowance provided, } \\
\text { enough to afford basic housing/ Free basic housing provided), 4. Length of commitment ( } 2 \text { years vs. } 5 \\
\text { years), 5. Support from manager (Not supportive vs. Supportive), } 6 \text {. Future tuition (Not provide any } \\
\text { financial assistance vs. Provide full tuition for a study program) }\end{array}$ & Future tuition \\
\hline 6 & $\begin{array}{l}\text { Rao, } \\
2013\end{array}$ & India & $\begin{array}{l}\text { 1. Staff (Few staff and heavy workload vs. Fully staffed and moderate workload), } 2 \text {. Area (Located in a } \\
\text { poorly connected place with bad education facility for children and poor housing provided/ Located in a } \\
\text { poorly connected place with bad education facility for children but good housing provided/ Located in a } \\
\text { well-connected place, having good education facilities for children but poor quality housing provided/ } \\
\text { Located in a well-connected place, having good education facilities for children and good quality hous- } \\
\text { ing provided), } 3 \text {. Health center infrastructure (Building in poor condition, inadequate equipment, and } \\
\text { frequent shortages of supplies and drugs vs. Well-maintained building, adequately equipped with few } \\
\text { shortages of supplies and drugs), } 4 \text {. Salary ( } 30000 \mathrm{Rs} / 45000 \mathrm{Rs} / 65000 \mathrm{Rs} / 80000 \mathrm{Rs),} 5 \text {. Change in } \\
\text { location to city or town (Uncertain vs. On completion of } 3 \text { years), } 6 \text {. Professional development (Short- } \\
\text { duration training courses for skill development/ Easier admission to PG after } 3 \text { years of service in same } \\
\text { job through reservation), } 7 \text {. Job location (Not located in your native area vs. Located in your native } \\
\text { area), } 8 \text {. Type of health center (Clinic/ Small hospital ( } 20-30 \text { beds)/ Large hospital ( } 50-100 \text { beds)) }\end{array}$ & $\begin{array}{l}\text { Good educa- } \\
\text { tion facilities } \\
\text { for children }\end{array}$ \\
\hline 7 & $\begin{array}{c}\text { Lagarde, } \\
2013\end{array}$ & Thailand & $\begin{array}{l}\text { 1. Hospital size (Small }(10-60 \text { beds) vs. Large ( }>60 \text { beds) }), 2 \text {. Hospital location (In or near your home } \\
\text { province vs. A province far from your home province), 3. Your monthly salary (Base/ Base }+15 \% \text { / } \\
\text { Base }+30 \% \text {; Base }+45 \%), 4 \text {. Night shifts per month }(7 \text { vs. } 14) \text {, 5. Presence of a consultant in the facility } \\
\text { (Yes vs. No), } 6 \text {. Reserved quota for subsequent specialist training (Yes vs. No), } 7 \text {. Number of years you } \\
\text { have to wait to be promoted to the next grade ( } 1 \text { vs. } 2 \text { ) }\end{array}$ & $\begin{array}{c}\text { Increased } \\
\text { salary }\end{array}$ \\
\hline 8 & $\begin{array}{c}\text { Rafiei, } \\
2015\end{array}$ & Iran & $\begin{array}{l}\text { 1. Location (Rural vs. Urban), 2. Income (Base/ Base }+100 \% \text {; Base }+150 \% \text {; Base }+200 \% \text { ), 3. Dual prac- } \\
\text { tice (Yes vs. No), } 4 \text {. Workload (Light/ Moderate/ Heavy), 5. Proximity to family (Yes vs. No), } 6 \text {. Clini- } \\
\text { cal infrastructure (Inadequate vs. Adequate), 7. Housing (None/ Basic/ Superior), } 8 \text {. Educational facili- } \\
\text { ties (Basic vs. Superior) }\end{array}$ & $\begin{array}{l}\text { Increased } \\
\text { salary }\end{array}$ \\
\hline 9 & $\begin{array}{c}\text { Robyn, } \\
2015\end{array}$ & Cameroon & $\begin{array}{l}\text { 1. Career development (No preferential admission for health workers in rural areas for ongoing training } \\
\text { available vs. Establishment of preferential admission for ongoing training available to your level via a } \\
\text { quota of } 20 \% \text { of seats reserved for those who worked for at least } 4 \text { years in rural areas), } 2 \text {. Accessibility } \\
\text { and connectivity of the workplace to the city (Your facility is located in a village with poor connectivity } \\
\text { - reliable transportation to the health district capital twice a week or less vs. Your facility is located in a } \\
\text { village with good connectivity - reliable transportation to the health district capital every day), 3. Health } \\
\text { facility infrastructure (Lack of equipment, drugs and so on vs. Adequate equipment, drugs and so on), } 4 \text {. } \\
\text { Lodging (No accommodation provided vs. A good quality house is made available in a secure location } \\
\text { with access to drinking water), 5. Salary (Base/ Base }+25 \% / \text { Base }+50 \% / \text { Base }+75 \% \text { ), } 6 \text {. Job assignment } \\
\text { in an urban area (Uncertain vs. Automatic after } 3 \text { years) }\end{array}$ & $\begin{array}{l}\text { Bonus of } \\
75 \% \text { of base } \\
\text { salary }\end{array}$ \\
\hline 10 & $\begin{array}{l}\text { Efendi, } \\
2015\end{array}$ & Indonesia & $\begin{array}{l}\text { 1. Quality of facility (Basic vs. Advanced), 2. Housing (No housing or allowance provided/ Housing } \\
\text { allowance provided, enough to afford basic housing/ Free basic housing provided), } 3 \text {. Length of com- } \\
\text { mitment (1-year vs. 2-year), } 4 \text {. Study assistance (Not provide any financial assistance vs. Provide full } \\
\text { tuition), } 5 \text {. Salary per month ( } 3 \text { million IDR* } 5 \text { million IDR/ } 7 \text { million IDR/ } 10 \text { million IDR), } 6 \text {. Man- } \\
\text { agement (Limited support vs. Full support) }\end{array}$ & $\begin{array}{l}\text { Study assis- } \\
\text { tance }\end{array}$ \\
\hline 11 & $\begin{array}{l}\text { Holte, } \\
2015\end{array}$ & Norway & $\begin{array}{l}\text { 1. Location }(<5000 \text { inhabitants/ } 5000-14,999 \text { inhabitants/ } 15000-49,999 \text { inhabitants/ }>50000 \text { inhabit- } \\
\text { ants), } 2 \text {. Opportunity to control working hours (Limited vs. Very good), } 3 \text {. Opportunity for professional } \\
\text { development (Limited vs. Very good), } 4 \text {. Income }(10 \% \text { less than average salary for hospital doctors/ } \\
\text { Equal to the average salary for hospital doctors/ } 10 \% \text { above the average salary for hospital doctors/ } 20 \% \\
\text { above the average salary for hospital doctors), } 5 \text {. Practice size }(1-2 \text { doctors/ } 3-5 \text { doctors/ } 6 \text { doctors or } \\
\text { more) }\end{array}$ & $\begin{array}{l}\text { Non- } \\
\text { pecuniary } \\
\text { attributes }\end{array}$ \\
\hline 12 & $\begin{array}{l}\text { Rana, } \\
2016\end{array}$ & Pakistan & $\begin{array}{l}\text { 1. Career Promotion (Commitment for two years/ Commitment for } 3 \text { years and then upgrading/ Com- } \\
\text { mitment for } 5 \text { years and then upgrading), } 2 \text {. Quality of the Facility (Basic vs. Advanced), } 3 \text {. Salary } \\
\text { (Base }+10 \% \text {; Base }+30 \%, 15 \% \text { annual increment/ Base }+50 \%, 10 \% \text { annual increment), } 4 \text {. Living Condi- } \\
\text { tion (No housing facility/ Housing and security allowance/ Housing availability with basic amenities), } 5 \text {. } \\
\text { Transportation (Availability of transport vs. Transport allowances), } 6 \text {. Study Assistance (No support/ } \\
\text { Partial Financial support/ Full Financial support) }\end{array}$ & High salary \\
\hline 13 & $\begin{array}{l}\text { Smitz, } \\
2016\end{array}$ & Timor-Leste & $\begin{array}{l}\text { 1. Facility type (Community Health Center vs. Health Post), 2. Location (Urban/ Remote/ Extremely } \\
\text { remote), 3. Health Facility Equipment (Good level/ Medium level/ Poor), 4. Housing (Good vs. Poor), } 5 . \\
\text { Transportation (Motorbike vs. No motorbike), 6. Income ( } 610 \text { USD*/ } 732 \text { USD/ } 854 \text { USD), 7. Training } \\
\text { (None/ Workshops/ Visits from Specialist/ Higher Edu) }\end{array}$ & $\begin{array}{l}\text { Training and } \\
\text { education }\end{array}$ \\
\hline 14 & $\begin{array}{l}\text { Witt, } \\
2017\end{array}$ & Canada & 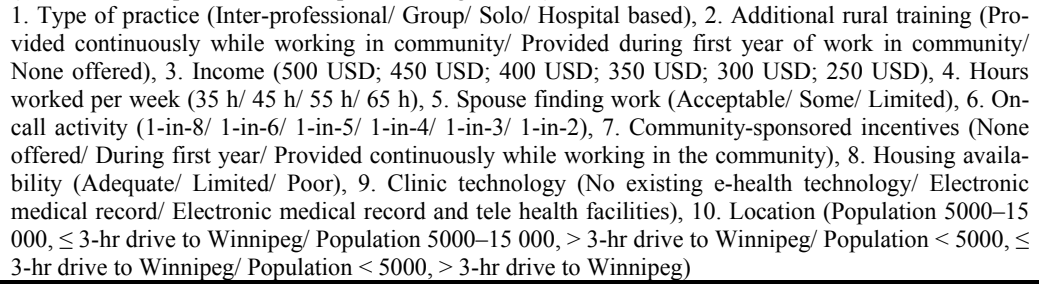 & Income \\
\hline
\end{tabular}

VND= Vietnamese dong; PEN= Peruvian Sol; USh= Ugandan shilling; Rs= Indian rupee; IDR= Indonesia Rupiah; USD= United States Dollar

studies identify the "improving equipment" (22) and "good education facilities for children" (25) to be the most important attributes for respondents (Table 3).

\section{Discussion}

This systematic review aimed to investigate which attributes were included in DCE studies and which of them was the most important. In this study, various attributes were identified that affect physicians' willingness to work- 
ing in deprived areas. The included studies were done in different countries, which use different financial and nonfinancial incentives to elicit physician's preferences for working in deprived areas.

Different economic, social and cultural conditions of countries can have a different effect on the physicians' preferences for working in deprived areas. Accordingly, it can be said that the type of motivation is different for physicians from one country to another. For example, in some countries, on the one hand increasing salaries and incomes will have a greater impact on physician's decisions (15, $16,18,20,23,24,26)$, and on the other hand, in other countries, these attributes have less impact on the physician's preferences $(21,25,28)$. According to the results, it can be concluded that focusing solely on increasing salaries or incomes without considering other attributes, cannot have long-term effects; because financial incentives are one of the interventions intended to improve the shortage of physicians in deprived areas.

Identification of attributes and their levels is a major step in the DCE. Although there is no precise method for identifying attributes and levels, literature review and qualitative research usually used for this purpose $(2,29)$. Therefore, the use of any of these methods alone can lead to the identification of various attributes and consequently results in different findings. In general, only a few studies $(29 \%)$ use both reviews and qualitative methods simultaneous to elicit attributes and attribute-levels (15, 16, 19, 27).

In-service physicians and medical students had different views on the attributes that influenced their preferences for working in deprived areas; of the total (9 studies) that examined in-service physicians, based on the results of 7 studies $(67 \%)$, increasing salaries and incomes increases the likelihood of their attraction or their retention to deprived areas. Of the total of 7 studies focused on medical students, only 2 studies (29\%) reported that salaries increase had an impact on the medical students to attract to deprived areas.

\section{Strengths of the study}

The results of this review can provide useful information on which package of attributes, policies should be focused and can be helpful for researchers in conducting a DCE study to provide policy options for attracting and recruiting physicians to deprived areas.

\section{Limitations of the study}

Many different factors such as study question, identifying the attributes and levels, the number of the attributes, the levels of attribute and variation in analyzing the data affect the results of DCE studies, so comparing the results of included studies, is not possible directly. Furthermore, because only English language studies included in this review, some relevant studies may be ignored. This study only reviews the studies done with the DCE method and has not investigated studies done with other methods for extracting preferences (such as conjoint analysis).

\section{Conclusion}

Financial attributes are not the only significant attributes considered by the physicians for deciding where to practice, but also the other non-financial attributes are important. It is suggested, that based on the economic, social and cultural conditions of each country, a specific incentive package, including a set of financial and non-financial incentives, is developed to attract physicians to the deprived areas.

\section{Acknowledgments}

This study has been extracted from Ph.D. thesis of first author, Pejman Hamouzadeh (thesis code: 9021383002), and funded by Tehran University of Medical Sciences.

\section{Conflict of Interests}

The authors declare that they have no competing interests.

\section{References}

1. World Health Organization. Increasing access to health workers in remote and rural areas through improved retention: global policy recommendations. Geneva: World Health Organization; 2010.

2. Ryan M, Kolstad J, Rockers P, Dolea C. How to conduct a discrete choice experiment for health workforce recruitment and retention in remote and rural areas: a user guide with case studies. World Health Organization \& CapacityPlus: World Bank. 2012.

3. Dumont JC, Zurn P, Church J, LeThi C. International mobility of health professionals and health workforce management in Canada: myths and realities. OECD. Health working paper; 2008.

4. Ricketts TC, Hart LG, Pirani M. How many rural doctors do we have? J Rural Health. 2000;16(3):198-207.

5.Zurn P, Codjia L, Sall FL, Braichet JM. How to recruit and retain health workers in underserved areas: the Senegalese experience. Bull World Health Organ. 2010;88(5):386-9.

6. Lemiere C, Herbst C, Jahanshahi N, Smith E, Soucat A. Reducing geographical imbalances of health workers in sub-Saharan Africa: a labor market perspective on what works, what does not, and why: World Bank Publications; 2010.

7. Rao KD, Bhatnagar A, Berman P. So many, yet few: human resources for health in India. Hum Resour Health. 2012;10(1):19.

8. Mangham LJ, Hanson K, McPake B. How to do (or not to do).. Designing a discrete choice experiment for application in a lowincome country. Health Policy Plann. 2009;24(2):151-8.

9. Takemura T, Kielmann K, Blaauw D. Job preferences among clinical officers in public sector facilities in rural Kenya: a discrete choice experiment. Hum Resour Health. 2016;14(1):1.

10. Kolstad JR. How to make rural jobs more attractive to health workers. Findings from a discrete choice experiment in Tanzania. Health Econ. 2011;20(2):196-211.

11. Honda A, Vio F. Incentives for non-physician health professionals to work in the rural and remote areas of Mozambique - a discrete choice experiment for eliciting job preferences. Hum Resour Health. 2015;13(1):23.

12. Ageyi-Baffour P, Rominski S, Nakua E, Gyakobo M, Lori JR. Factors that influence midwifery students in Ghana when deciding where to practice: a discrete choice experiment. BMC Med Educ. 2013;13:64.

13. Huicho L, Miranda JJ, Diez-Canseco F, Lema C, Lescano AG, Lagarde M, et al. Job Preferences of Nurses and Midwives for Taking Up a Rural Job in Peru: A Discrete Choice Experiment. PLoS One. 2012;7(12).

14. Munga MA, Torsvik G, Maestad O. Using incentives to attract nurses to remote areas of Tanzania: a contingent valuation study. Health Policy Plann. 2014;29(2):227-36.

15. Miranda JJ, Diez-Canseco F, Lema C, Lescano AG, Lagarde M, Blaauw D, et al. Stated preferences of doctors for choosing a job in rural areas of Peru: a discrete choice experiment. PLoS One. 2012;7(12):e50567. 
16. Rana SA. Job Preferences of Doctors for Working in Rural Islamabad Capital Territory, Pakistan: a Discrete Choice Experiment. J Healthc Commun. 2016;2(1).

17. Vujicic M, Shengelia B, Alfano M, Thu HB. Physician shortages in rural Vietnam: using a labor market approach to inform policy. Soc Sci Med. 2011;73(7):970-7.

18. Witt J. Physician recruitment and retention in Manitoba: results from a survey of physicians' preferences for rural jobs. Can J Rural Med. 2017;22(2):43-53.

19. Efendi F, Chen CM, Nursalam N, Andriyani NW, Kurniati A, Nancarrow SA. How to attract health students to remote areas in Indonesia: a discrete choice experiment. Int J Health Policy Manag. 2015;31(4):430-45.

20. Hanson K, Jack W. Incentives Could Induce Ethiopian Doctors And Nurses To Work In Rural Settings. Health Aff. 2010;29(8):1452-60.

21. Holte JH, Kjaer T, Abelsen B, Olsen JA. The impact of pecuniary and non-pecuniary incentives for attracting young doctors to rural general practice. Soc Sci Med. 2015;128:1-9.

22. Kruk ME, Johnson JC, Gyakobo M, Agyei-Baffour P, Asabir K, Kotha SR, et al. Rural practice preferences among medical students in Ghana: a discrete choice experiment. Bull World Health Organ. 2010;88(5):333-41.

23. Lagarde M, Pagaiya N, Tangcharoensathian V, Blaauw D. One size does not fit all: investigating doctors' stated preference heterogeneity for job incentives to inform policy in Thailand. Health Econ. 2013;22(12):1452-69.

24. Rafiei S, Arab M, Rashidian A, Mahmoudi M, Rahimi-Movaghar V. Policy interventions to improve rural retention among neurosurgeons in Iran: A discrete choice experiment. Iran J Neurol. 2015;14(4):2118.

25. Rao KD, Ryan M, Shroff Z, Vujicic M, Ramani S, Berman P. Rural clinician scarcity and job preferences of doctors and nurses in India: a discrete choice experiment. PLoS One. 2013;8(12):e82984.

26. Robyn PJ, Shroff Z, Zang OR, Kingue S, Djienouassi S, Kouontchou $\mathrm{C}$, et al. Addressing health workforce distribution concerns: a discrete choice experiment to develop rural retention strategies in Cameroon. Int J Health Policy Manag. 2015;4(3):169-80.

27. Rockers PC, Jaskiewicz W, Wurts L, Kruk ME, Mgomella GS, Ntalazi F, et al. Preferences for working in rural clinics among trainee health professionals in Uganda: a discrete choice experiment. BMC Health Serv Res. 2012;12:212.

28. Smitz MF, Witter S, Lemiere C, Eozenou PHV, Lievens T, Zaman $\mathrm{RU}$, et al. Understanding health workers' job preferences to improve rural retention in Timor-leste: Findings from a discrete choice experiment. PLoS One. 2016;11(11).

29. Kleij K-S, Tangermann U, Amelung VE, Krauth C. Patients' preferences for primary health care-a systematic literature review of discrete choice experiments. BMC Health Serv Res. 2017;17(1):476. 